\title{
Oskar Szwabowski
}

Uniwersytet Szczeciński

\section{Autonomia, exodus, zaangażowanie}

Autonomia to niebezpieczny mit. Mit, który nie tylko nie jest w stanie obronić uczelni przed neoliberalną transformacją, lecz także może wspierać destrukcyjne tendencje kapitalizmu. Wychodząc od tego stwierdzenia, od grozy złego mitu, przejdę do wskazania, że widmo, a może upiór autonomii, ujawnia się również w niektórych koncepcjach krytycznych postulujących exodus jako formę istnienia i o(d)poru1. Następnie rozwinę myślenie utopijne, postulując zaangażowanie jako podstawę krytycznego, rewolucyjnego, złożonego uniwersytetu, który mógłby wspierać demokrację, sprawiedliwość społeczną oraz powstrzymywać i zastępować destrukcyjne tendencje współczesnego kapitalizmu. Prezentowane rozważania są oczywiście propozycją, należy je traktować jako zaproszenie do dyskusji. Nowy uniwersytet, tak samo jak nowe społeczeństwo, może się wyłonić w realnym dialogu, we wspólnej pracy. Wspólność pracy, wspólność dialogu, horyzontalna demokracja są w moim mniemaniu zarówno podstawą, środkiem, jak i celem, tak uniwersytetu, jak i społeczeństwa. Zasada taka jest fundamentalna w tym sensie, w jakim wszelkie zasady są fundamentów pozbawione².

\section{Autonomia, która nawiedza, i horror kapitalizmu}

Autonomia jest istotnie powiązana z liberalizmem, z jego wizją podmiotu, wolności i bytu społecznego jako takiego (Christman, Anderson, 2005). W tekście odwołuję się do liberalnego ujęcia autonomii, które zresztą rozpowszechnione jest $\mathrm{w}$ dyskursie o uniwersytecie. Koncepcji liberalnej nie poddaję szczegółowej krytyce, gdyż tej dokonał społeczny anarchista Bookchin (2006), a ja ją przyjmuję. W odniesieniu do uniwersytetu, poza liberalno-oświeceniową tradycją, majaczą $w$ niej wizje średniowieczne. Fantazja autonomii uniwersytetu zdaje się czerpać z tychże źródeł. Niektórzy badacze podejmujący problem

1 „O(d)pór” rozumiem za Rutkowiak (2009). Również za Rutkowiak podzielam przekonanie o jego konieczności.

2 Odwołuję się tutaj do rozważań Rorty'ego dotyczących solidarności (Rorty, 2009).

3 Kategorię „horror kapitalizmu” zaczerpnąłem z pracy Stańczyka (2013). 
autonomii wskazują, że to właśnie średniowieczne uniwersytety cieszyły się pełną prawdziwą autonomią - o tyle, o ile była to instytucja zewnętrzna, istniejąca niemal poza społeczeństwem (Guzmàn-Valenzuela, 2018, s. 5) .

W pierwszym odruchu widmo autonomii może nam się wydać duchem, co przybył, by wesprzeć nas w walce - inspirować $\mathrm{i}$ rysować utopijne wizje. Neoliberalne transformacje uniwersytetu, zwłaszcza jego wersje określane mianem przedsiębiorczego uniwersytetu, prowadzą do podporządkowania instytucji. Zostaje on przekształcony w „transnarodową biznesową korporację". Poddany nowym mechanizmom kontroli zostaje ulokowany w kleszczach między wymaganiami rynku a wymaganiami rządu - to podwójne zniewolenie niekiedy wywołuje napięcia, niekiedy współgra, żadne jednak nie upodmiotawia ludzi uniwersytetu. Tracą oni wpływ na instytucje, kształcenie i badania (Shore, Taitz, 2012). Autonomia wydawałaby się lekiem na takie zniewolenie. Jej duch miałby nas chronić przed intensyfikacją wyzysku, pogłębieniem alienacji i dalszym transformowaniem instytucji. Autonomia jako rodzaj sztandaru inspirowałaby do oporu i odporu.

Sztompka uznaje autonomię za podstawę uniwersytetu, za jego istotową cechę, która warunkuje właściwe funkcjonowanie: „autonomia i wytworzony przez nią kapitał społeczny to warunek sine qua non realizacji misji odkrywczej, innowacyjnej, dydaktycznej i kulturowej" (Sztompka, 2017, s. 34). Autonomia jest u Sztompki nie tylko postępowaniem na własny sposób, lecz także stanowi kluczowy termin przy określaniu, czym jest uniwersytet. Następuje tutaj swoiste zapętlenie ukazujące podwójną funkcję autonomii. Pierwsza to antykolonizacyjna funkcja - odcinanie się i budowanie barier między innymi polami czy - jak chce Sztompka - kulturami. Uniwersytet ma własną kulturę, własnego ducha, który nie może być naruszany przez „innych”. „Każde odchylenie, wtręt z innej kultury podważają autonomię uniwersytetu, powodują erozję i mogą ostatecznie zniszczyć kulturę akademicką. Dzisiejszy kryzys uniwersytetu ma źródło w inwazji innych kultur, obcych jego naturze, na kulturę akademicką" (Sztompka, 2017, s. 34). Tworzenie granicy jest jednocześnie definiowaniem samego uniwersytetu. Definiowanie jest równoważne ze stwarzaniem. Sztompka nie odwołuje się do istniejącego uniwersytetu, do jego konkretnych empirycznych przejawów, ale dzięki autonomii tworzy jego typ pożądany. Zaczyna kreślić wizje utopijne.

W tym kontekście widmo autonomii nie tylko miałoby nas chronić, lecz także pomagałoby stworzyć nowy uniwersytet. W wydaniu Sztompki mamy raczej do czynienia z formą retroutopii (Kochan, 2007). Próby ukonstytuowania czegoś w rodzaju oświeceniowego uniwersytetu, w której to wizji autonomii i uniwersytetu liberalne schematy grają istotną rolę. Mało tego, dostrzec można mistyfikującą rolę takich rozważań. Po pierwsze, nie jest jasno scharakteryzowane, kogo możemy uznać za ludzi uniwersytetu - nie tyle w sensie

4 Historycznie taka teza wydaje się problematyczna, chociażby dlatego, że nie ma jednego uniwersytetu średniowiecznego, a jego odmiany inaczej organizowały relacje władzy zarówno wewnątrz instytucji, jak i w relacjach do całości społecznej (zob. Baszkiewicz, 1997; Le Goff, 1997). Można przypuszczać, że w odwołaniu do tradycji średniowiecznej mamy do czynienia z kolejnym mitem. 
etosu, ile w sensie formalnym: do kogo należy uniwersytet. Nie jest to sprawa marginalna. W Polsce dominuje model uniwersytetu należącego do profesorów, gdzie marginalizacji ulegają inni członkowie - doktorzy, studenci czy pracownicy administracyjni (zob. Kwiek, 2015). Dodatkowo założona wspólnota ma jakiś magiczny wspólny zmysł, który pozwala rozpoznawać swoich od obcych, a tym samym skutecznie wykluczać ludzi, którzy są nośnikami innej kultury i mogą doprowadzić do kolonizacji od wewnątrz. Po drugie, następuje ostre cięcie między tym, co polityczne a tym, co naukowe, akademickie. Jak pisze Sztompka (2017, s. 33):

autonomia oznacza szczelną barierę od polityki: polityka winna się znaleźć poza murami uniwersytetu. Działa to w dwie strony: wchodząc na salę wykładową czy do pracowni badawczej, naukowcy powinni swoje poglądy ideologiczne i polityczne pozostawiać niczym płaszcz w szatni (Max Weber). I odwrotnie - wychodząc z roli naukowej do polityki czy mediów, w szatni powinni pozostawić akademicką togę. Niestety bariera ta jest naruszana w obie strony. Uniwersytet staje się terenem sporów politycznych i indoktrynacji, a profesura niekiedy otwarcie manifestuje swą stronniczość.

Pomijam problematyczność oddzielenia tego, co polityczne, od tego, co naukowe. Sam pozytywizm jest stanowiskiem politycznym, i to nie tylko w swojej fazie rewolucyjnej (zob. Gouldner, 1977). Problemem jest tutaj stosowanie dość schematycznego podziału nieuwzględniającego innych form polityki, które nie oznaczają powiązania nauki i uniwersytetu z „partią” (o typach powiązań polityki i edukacji zob. Szwabowski, 2017). Takie ujęcie nie tylko upraszcza zależności, lecz także działa wykluczająco. W wizji Sztompki nie ma miejsca dla krytycznych pedagogów ani osób widzących uniwersytet w kategoriach zaangażowania. Wykluczenie, ale zablokowanie - takie apolityczne ujęcie prowadzić będzie do swoistego wycofania się, a tym samym zablokowania pewnych dróg wyjścia z kryzysu. Wrócę do tego w dalszej części. Po trzecie, utopia Sztompki jest w pewnym sensie klasyczna, to znaczy nie przechodzi w utopistykę (Wallerstein, 2008). Nie wiadomo, jak wizja autonomicznego uniwersytetu miałaby wykiełkować z istniejących uniwersytetów. Śmiem twierdzić, że jego opis nie pasuje do realnie istniejących uniwersytetów, a samo oddzielenie od wpływów zewnętrznych nie musi doprowadzić do postulowanych zmian.

Mit autonomii ujawniający się w niektórych narracjach nie pyta o warunki możliwości ustanowienia tejże w ramach kapitalistycznego społeczeństwa, ani o warunki funkcjonowania samej instytucji - jest to retroutopia, która chciałaby przywrócić idealizowaną przeszłość. Oczywiście nie ma do końca jasności, do jakiej przeszłości konkretnie się odwołuje. To jest kolejny problem, który w niektórych liberalnych narracjach nie dostrzega ideologicznego, w sensie Althusserańskim (Althusser, 2006), wymiaru autonomii. Nie tylko zawiesza ona problem materialnych warunków możliwości, lecz także niekiedy zależności przedstawia jako niezależność. „Służenie rynkowi, podporządkowanie państwu tak, ale na naszych zasadach. Pozwólcie nam służyć po swojemu. Tak jakbyśmy byli wolni”. W tych trzech wypadkach mit autonomii jest niebezpieczny. W najlepszym razie skazuje nas na jałowość oporu, w najgorszym podporządkowuje nas jako istoty wolne. Autonomia utrzymuje iluzję o naszej wolności i samodzielności, o naszej indywidualności - a tym sa- 
mym reprodukuje strukturę wspierającą kapitalizm. Ponadto, patrząc z perspektywy krytycznej, nie jest do końca jasne, czy w obecnych czasach społecznego kryzysu, chwiania się demokracji, prekaryzacji i intensyfikacji wyzysku, odradzania się faszyzmów dążenie do autonomii jest pożądane.

\section{Studiowanie i exodus}

Nim przejdziemy do rozważania innego, powiedzmy, postautonomicznego myślenia o uniwersytecie, przyjrzyjmy się chwilę niektórym narracjom krytycznym związanym z paradygmatem studiowania ${ }^{5}$ (Lewis, 2013). W wydanej niedawno książce pod redakcją Ruitenberg, będącej próbą kontynuacji i rozszerzenia myślenia o studiowaniu, odnajdziemy bezpośrednie odwołania do tradycji średniowiecznej, do studiowania jako przestrzeni poza, w której obowiązują jej immanentne zasady, odpowiedni rytm i czas, nastrój i emancypacyjna bezcelowość. Przestrzeń studiowania zostaje odniesiona do przestrzeni świętej, bycie akademikiem do bycia mnichem; przestrzeń studiowania staje się miejscem spotkania z cudem, miejscem modlitwy - mnich i studiujący zostają zanurzeni w melancholii poza światem, poza państwem ziemskim i kapitalizmem (Ruitenberg, 2017).

Pojawia się pytanie, czy tak rozumiane studiowanie, które też ma być praktyką exodusu, nie prowadzi do intensyfikacji mitu autonomii, a słabą utopię Lewisa przekształca $\mathrm{w}$ retroutopię? Czy studiowanie, zamiast wspierać radykalną demokrację i rozwijać horyzontalną pedagogikę, nie prowadzi do odnowienia przywileju? Czy studiowanie, w ramach retroutopii, nie staje się kontemplacyjną praktyką dostępną dla wybranych, zamiast praktyką oporową dla wielości?

Czytając Lewisa, łatwo dostrzec swoiste pęknięcie w jego narracji, prześlizgiwanie się $\mathrm{z}$ tego, co polityczne, $\mathrm{w}$ to, co metafizyczne. Przy czym o ile zacieranie tych różnic samo w sobie nie jest niczym złym, a nawet jest pożądane, o tyle u Lewisa funkcjonują one jako dwa odrębne języki. Jego opowieść nie tyle zaciera, ukazując jedność, ile raczej zgrzyta, próbując połączyć dwie różne opowieści i dwie różne koncepcje w jedno. Ten zgrzyt ujawnia się w napięciu między autonomią a exodusem. Między mitem-metafizyką a utopią-polityką. Między klasztorem a ruchem Occupy.

Exodus, który również jest wycofaniem, który stwarza przestrzeń poza państwem i rynkiem, nie ma nic wspólnego $\mathrm{z}$ autonomią $\mathrm{w}$ rozumieniu liberalnym. Niewiele wspólnego ma również z retroutopią poza tym, że jest rodzajem, praktykowaniem utopii. Brak postulatów ruchu Occupy nie wiązał się jedynie z wycofaniem z polityki, z manifestacją niezależności, ale uruchomieniem innej polityki, kreacją innych przestrzeni. Ruch Occupy nie stwarzał oaz, jedynie chwilowych sfer autonomicznych, w których inne życie praktykowali studenci-aktywiści, wykolejeńcy i inni uprzywilejowani wykluczeni - był ogniskiem

5 Szerzej na temat koncepcji Lewisa pisałem w innym miejscu (zob. Szwabowski, 2015a). 
oporu, przestrzenią wybuchową, rakową (zob. Blumenkranz i in., 2012; Castells, 2013; De Zeeuw, 2014; Gelder, 2011; Gould-Wartofsky, 2015; Hannon, 2014; Kellner, 2013; Szwabowski, 2015b). Również bunty w Argentynie w 2001 roku nie tylko odrzucały politykę, nie tylko mówiły głośne „nie”, lecz także równocześnie mówiły „tak”, wiele „tak”, oddolnych „tak”, które wytwarzały alternatywne struktury społeczne, nowe, inne społeczeństwo, które funkcjonowało poza państwem i kapitalizmem, ale tak, aby je zastąpić czymś innym hierarchiczne struktury strukturami horyzontalnymi, kapitalizm kooperacją (zob. Sitri, 2006). Ogólnie mówiąc, najnowsze ruchy społeczne w przestrzeni studiowania i praktyki exodusu nie tyle opuszczają istniejące struktury, ile angażują się w tworzenie i chronienie dóbr wspólnych. Są ruchami zaangażowanymi, ukazującymi złożoność i zależność różnych elementów. Wskazują raczej na konieczność solidarności, zależność jednych istnień od drugich, niż rozwijają mit autonomicznego ja czy autonomicznej zbiorowości.

Przyglądając się studiowaniu $\mathrm{w}$ radykalnie demokratycznych ruchach społecznych, można stwierdzić, że exodus jest ruchem rewolucyjnym, oddolnie, wspólnie przekształcającym świat. Autonomia zaś, biorąc pod uwagę to, co powiedziano wyżej, jest ruchem wycofania, osadzonym w tym, co istnieje, i lokującym się w danych strukturach na zasadzie przywileju.

\section{Widma zaangażowania}

Z perspektywy pedagogiki krytycznej uniwersytet istniejący poza społeczeństwem, kierowany immanentnymi zasadami studiowania ujętego metafizycznie, nie jest czymś godnym pożądania. Wycofanie się, zanurzenie w melancholii może i jest pewnego rodzaju oporem wobec konieczności aktualizowania, nieustannego rozwoju zdefiniowanego w kapitalistyczny sposób, przyjmuje jednak ono formę indywidualną lub, w najlepszym razie, formę małej wspólnoty - takie zgromadzenie stanowi schronienie, tymczasem „schron przed burzą już nie wystarcza” (Denzin, 2009, s. 55). Tak samo, jak wymyślanie teorii w oderwaniu od aktualnych problemów społecznych, co podkreśla w swoich pracach Giroux (2016), przeciwstawiając się redukowaniu, swoistej ucieczce pedagogów krytycznych w obszar teorii. Stajemy przed problemami globalnymi; neoliberalizm, chociaż martwy, jest wciąż żywy, a w swojej wampirycznej egzystencji staje się brutalniejszy, coraz bardziej faszystowski i destrukcyjny.

Uniwersytet może się wydawać jedną z instytucji o(d)porowych. Za taką funkcją opowiada się Rorty, który pisze: „Wszystkie uniwersytety godne tego miana zawsze stanowiły centrum protestów społecznych. Jeśli uniwersytety amerykańskie kiedyś przestaną być takimi centrami, stracą one szacunek do samych siebie, a także szacunek całego świata akademickiego" (Rorty, 2010, s. 95-96).

Słowa te są mi bardzo bliskie, współbrzmią i przywołują ideę, jaką dostrzegałem w uniwersytecie. Wychowany na historiach maja 1968, studentów postrzegałem w snach jako 
nowy proletariat, uniwersytet jako przestrzeń rozwijania krytycznych narzędzi, bazę inspirującą i organizującą społeczny opór. Nie muszę chyba dodawać, że nigdy się na taki uniwersytet nie dostałem. I nigdy na takim uniwersytecie nie pracowałem. Podobnie jak na uniwersytecie z opowieści Sztompki.

Ograniczenie krytycznej funkcji uniwersytetu związane jest z neoliberalnymi transformacjami, z zawężaniem się przestrzeni publicznej (Gilbert, 2013). Guzmàn-Valenzuela, tworząc typologię uniwersytetów, wymienia m.in. uniwersytet rewolucyjny, którego misją jest krytyka społeczna i partycypacja w transformacji społecznej, badania stanowią krytyczne dociekania, a dydaktyka oparta jest na pedagogice krytycznej. Dostrzega jednak, że jest to model, który występuje marginalnie, w ramach hybrydowości instytucji uniwersytetu. I nawet $\mathrm{w}$ swojej realizacji dostrzec można samoograniczanie się, m.in. przez redukcję pedagogiki krytycznej do wymiaru teoretycznego, oddzielonego od praktyki społecznej i realnego zaangażowania w konkretną zmianę społeczną, w konkretne walki, ruchy społeczne i związkowe (Guzmàn-Valenzuela, 2018, s. 11-12).

Przekroczenie samoograniczania, marginalizacji, wymaga rozpatrzenia warunków, w jakich uniwersytet może lub nie może zaistnieć. Prowadzi to do rozważenia zależności, które obecnie sprawiają, że na samoograniczanie nakłada się realne ograniczanie wszelkiej myśli krytycznej i dydaktyki innej niż neoliberalne szkolenie: czy to elit, czy to siły roboczej, w zależności od typu uniwersytetu. Wspomniana Guzmàn-Valenzuela proponuje model uniwersytetu złożonego, który wchłania w siebie uniwersytet radykalny i jest rozszerzeniem uniwersytetu ekologicznego. Jest to też w pewnym sensie radykalizacja uniwersytetu rewolucyjnego. Uniwersytet złożony zakłada wiele dróg produkowania wiedzy i wielość spojrzeń na świat, dydaktykę otwartą na wyzwania globalnego obywatelstwa nie tylko wytwarza nowe ramy rozumienia, lecz także zmienia świat na lepsze (Guzmàn-Valenzuela, 2018, s. 14).

\section{Praktykowanie utopii-propozycje}

Po egzorcyzmowaniu autonomii, ujawnieniu jej demonicznego, upiornego oblicza, można się zastanowić nad alternatywnymi sposobami ujęcia uniwersytetu w kryzysie oraz zarysowaniu dróg wyjścia z niego.

1. Można wprowadzić pewne rozdzielenie na uniwersytet jako formalną instytucję oraz na uniwersytet jako praktykę czy zdarzenie (zob. Bauman, Jendza, 2016) - co oczywiście nie wyklucza kontrinstytucjonalizacji. Formalna instytucja to miejsce pracy poddane określonym wymogom, to „transnarodowa korporacja biznesowa” (Shore, Taitz, 2012, s. 205); uniwersytet-wydarzenie może powstawać zarówno w murach formalnej instytucji, gdzieś w piwnicach, poza kontrolą i wyliczalnością, jak i poza murami, chociażby w stowarzyszeniach czy ruchach społecznych, ale równie dobrze w słynnych kuchniach. To rozdzielenie jest dość ważne dla analizy i praktyk oporowych. To są jakby dwie inne 
przestrzenie - można spokojnie prowadzić refleksje, ignorując którąś z nich. Można potraktować uniwersytet-instytucję po prostu jako miejsce pracy - z kiepską pensją, toksycznymi relacjami (Pelias, 2017, s. 364) oraz, jak powiedział jeden z pracowników, „discopolowym menadżeryzmem”. Biorąc pod uwagę polską kulturę organizacji pracy, na nic więcej liczyć nie można. Można praktykować uniwersytet, nie będąc pracownikiem uniwersytetu-instytucji. Tak samo jak, będąc pracownikiem uniwersytetu-instytucji, można mieć niewiele wspólnego z uniwersytetem jako praktyką. Wyzwaniem jest połączenie tych przestrzeni tak, aby służyły one wytwarzaniu i trosce o dobra wspólne ${ }^{6}$.

2. O ile wszelka walka o lepsze warunki pracy jest jak najbardziej pożądana, o tyle w przypadku uniwersytetu natrafia ona na kilka istotnych problemów ${ }^{7}$ :

a) walka o godną pracę i płacę $\mathrm{w}$ ramach samego uniwersytetu wpisuje się w problem autonomii i może generować myślenie, że neoliberalizm jest dobry dla fizycznych, ale nie dla naukowców (zob. Szwabowski, 2016); część akademików wspierała reformy neoliberalne; niektóre władze uniwersyteckie aktywnie prekaryzowały najsłabszych członków wspólnoty, jak chociażby w słynnej sprawie sprzątaczek a Poznania (OZZIP, 2014; Szymaniak, 2018, s. 20) - takie podejście, operujące na przywileju, zrzeka się krytyki społecznej, stając się jedynie krytyką wewnętrzną;

b) dodatkowo wyklucza grono osób, bez których uniwersytet jako instytucja nie mógłby funkcjonować; moim zdaniem jest to krytyka, która opiera się na braku solidarności zarówno wewnętrznej (najsłabsi członkowie i członkinie wspólnoty), jak i zewnętrznej, braku solidarności ze światem pracy jako takim; może to prowadzić do mistyfikacji pracy akademickiej, jak również do rozkwitu retroutopii, nie mówiąc już o wycofaniu się z krytyki społecznej i walki o lepszy świat nie tylko w akademii;

c) uniwersytet sam ogranicza tę walkę, swoje warunki przetrwania i możliwości działania - widoczne to było podczas dyskusji na temat reformy, kiedy minister spokojnie narzucał swoją wolę pracownikom akademickim, wskazuje to, że taka praktyka nie przekracza zakleszczenia między urządowieniem i prywatyzacją, w jakich

6 Bauman i Jendza (2016) dostrzegają, że podział na instytucje i wydarzenie jest bardzo uproszczony i nie uwzględnia problemu złożoności. Uwzględnienie złożoności i wzajemnych relacji między wydarzeniem a instytucją jest wyzwaniem dla emancypacyjnej praktyki. Wymagają one jednak konkretnej analizy i praktyki, nie zaś filozoficznej spekulacji.

7 Winn (2015) wskazuje na problem ujęcia pracy akademickiej, postulując stosowanie metody marksistowskiej. Uważa on m.in., że koncentracja na samych warunkach pracy jest jałowa i rozgrywa się na terenie myślenia sfetyszyzowanego. Proponuje uwzględnienie w analizach tego, w jakim sensie uniwersytet jest fabryką wiedzy włączoną w kapitalistyczny system produkcji. W samej analizie pracy jako działania pragnie odnaleźć wyjście poza kapitalizm. O ile zgadzam się z krytycznymi uwagami dotyczącymi typowego ujmowania pracy akademickiej i z zagrożeniami mistyfikacji samej pracy, o tyle wydaje mi się, że próba wypracowania radykalnej krytyki pracy (nie tylko akademickiej) wymaga przestrzeni wspólnej, gdzie pracownicy wykraczają poza swoje bycie pracownikiem. Inaczej mówiąc, podstawą jest założenie, że praca akademicka jest pracą wykonywaną w ramach społeczeństwa kapitalistycznego. Zaś odzyskanie władzy nad produkcją wiedzy jako dobra wspólnego nie ogranicza się jedynie do udziału samych ludzi akademii. 
znajdują się współczesne uniwersytety (Shore, Taitz, 2012, s. 216). Nie uwzględnia również złożoności relacji między instytucją a zewnętrzem ${ }^{8}$.

3. Zakwestionowanie prekaryzacji, neoliberalnych praktyk winno mieć wymiar globalny i opierać się na szerokiej solidarności. Uniwersytet zarówno jako praktyka, jak i instytucja winien zostać uznany za element całości, istotnie z nią powiązany i jej służący. Służba nie oznacza oczywiście podległości władzy państwowej czy rynkowi, ale jako dobro wspólne wymaga wywiązania się z tych pęt i nawiązania relacji z tym, co społeczne. Transformacja samej instytucji oraz praktyki, która nie będzie oparta na przywileju czy ograniczała się do wąskiej grupy, wymaga zaangażowania w transformację samego społeczeństwa. Dobrym przykładem tworzenia takiego zaangażowanego uniwersytetu jest ruch związkowy pracowników akademickich, który nie tylko rozpoczynał szeroką współpracę z innymi pracownikami spoza akademii, lecz także włączał się w działania ruchów społecznych - transformując zarówno uniwersytet, jak i społeczeństwo, tworząc demokratyczne wspólnoty i formułując problemy szerzej niż tylko zredukowane do problemów warunków pracy (Gilbert, 2013).

4. Przejście w stronę wiedzy zaangażowanej, w stronę praktyki społecznej opartej na tworzeniu i trosce o dobra wspólne, prowadzi do połączenia myślenia o uniwersytecie jako instytucji i praktyce. Zależność nie staje się problemem, ale warunkiem funkcjonowania uniwersytetu. Wskazuje na szeroką wspólnotę, która nie ogranicza się jedynie do ludzi uniwersytetu, jak i do samych ludzi, ale rozwija myślenie ekologiczne. Uniwersytet staje się własnością wspólną, realizując tym samym sens utrzymywania instytucji z podatków, które są skorumpowaną formą solidarności społecznej. Demokratyzacja instytucji, tak jak demokratyzacja zarządzania podatkami, powiązana jest $\mathrm{z}$ demokratyzacją całości społecznej. Oznacza to jak najszerszą partycypację w ramach horyzontalnych, mobilnych struktur. Uniwersytet niejako roztapia się w tym, co społeczne, zaciera się jego specyfika i wyodrębnienie. Znika autonomia, a na jej miejsce pojawiają się radykalna demokracja, solidarność i zaangażowanie.

To, jak konkretnie zorganizować taki uniwersytet, jest kwestią dyskusji i wspólnej praktyki, która będzie jednocześnie tworzeniem takiego uniwersytetu. Pewne idee dostrzegam $\mathrm{w}$ dociekaniach robotniczych, ale nie należy ich absolutyzować - a raczej wspierać pluralizm badań i sposobów zaangażowania. Transformacja uniwersytetu wiąże się na pewno $\mathrm{z}$ ingerencją $\mathrm{w}$ palące problemy społeczne, ze wspieraniem wykluczonych, ludzi pracy i przeciwdziałaniu prekaryzacji, faszyzacji i destrukcji naszego wspólnego świata. Transformacja uniwersytetu, o(d)pór wobec kapitalistycznej produkcji, wymaga zaangażowania w zmianę samego świata, w którym ulokowany jest uniwersytet.

8 Warto wspomnieć, że na taki brak narażone są również, o czym już wspominałem, narracje dotyczące uniwersytetu jako praktyki - kiedy zanurzają się w ideologii autonomii i dostrzegają praktykę jako działania jednostek. 


\section{Bibliografia}

Althusser, L. (2006). Ideologie i aparaty ideologiczne państwa. Pobrane z: http://recyklingidei.pl/althusser-ideologie-aparaty-ideologiczne-panstwa (12.05.2018).

Baszkiewicz, J. (1997). Młodość uniwersytetów. Warszawa: Wydawnictwo Żak.

Bauman, T., Jendza, J. (2016). Ciemne i jasne metafory dialogowania w uniwersytecie. Studia i Badania Naukowe, 10 (1), 107-123.

Blumenkranz, C., Gessen, K., Greif, M., Leonard, S., Resnick, S., Saval, N., Schmitt, E., Taylor, A. (2012). Occupy: Sceny z okupowanej Ameryki. Warszawa: Wydawnictwo Krytyki Politycznej.

Bookchin, M. (2006). Anarchizm spoteczny czy anarchizm stylu życia? Przepaść nie do pokonania. Poznań: Oficyna Trojka.

Castells, M. (2013). Sieci oburzenia i nadziei. Ruchy spoleczne w erze internetu. Warszawa: Wydawnictwo Naukowe PWN.

Christman, J., Anderson, J. (2005). Introduction. W: J. Christman, J. Anderson (red.), Autonomy and the Challenges to Liberalism. New Essays (s. 1-23). Cambridge: Cambridge University Press.

Denzin, K.N. (2009). Qualitative Inquiry Under Fire. Toward a New Paradigm Dialogue. Walnut Creek, California: Left Coast Press.

De Zeeuw, D. (2014). Engaged Withdrawal. Occupying Politics Beyond Politics. Krisis. Journal for Contemporary Philosophy, 1, 68-78.

Gelder, von S. (2011). This Changes Everything. Occupy Wall Street and the 99\% Movement. San Francisco: Berrett-Koehler Publishers.

Gilbert, D.A. (2013). The Generation of Public Intellectuals: Corporate Universities, Graduate Employees and the Academic Labor Movement. Labor Studies Journal, 38 (1), 32-46.

Giroux, H.A. (2016). Toward a Politics of Revolt and Disruption. Higher Education in Dangerous Time. The Radical Imagine-Nation, 1 (1), 19-40.

Gouldner, A.W. (1977). Co zdarzyło się w socjologii: historyczny model rozwoju strukturalnego. W: J. Szacki (red.), Czy kryzys socjologii? (s. 127-296). Warszawa: Czytelnik.

Gould-Wartofsky, A.M. (2015). The Occupiers. The Making of the 99 Percent Movement. New York: Oxford University Press.

Guzmàn-Valenzuela, C. (2018). Universities, knowledge and pedagogical configuration: Glimpsing the complex university. Educational Philosophy and Theory, 50 (1), 5-17. DOI: https://doi.org/10.10 80/00131857.2017.1313717.

Hannon, A. (2014). "Whose Streets?": Zones of Performative Occupations. Transforming Anthropology. Journal of the Association of Black Anthropologists, 22 (1), 7-12. DOI: https://doi.org/10.1111/traa.12023.

Kellner, D. (2013). Media spectacle, insurrection and the crisis of neoliberalism from the Arab Uprisings to Occupy Everywhere! International Studies in Sociology of Education, 23 (3), 251-272. DOI: https://doi.org/10.1080/09620214.2013.790665.

Kochan, J. (2007). Życie codzienne w matriksie. Filozofia społeczna w postnowoczesności. Warszawa: Scholar.

Kwiek, M. (2015). Uniwersytet $w$ dobie przemian. Instytucje $i$ kadra akademicka $w$ warunkach rosnacej konkurencji. Warszawa: Wydawnictwo Naukowe PWN. 
Le Goff, J. (1997). Inteligencja w wiekach średnich. Warszawa: Volumen.

Lewis, T.E. (2013). On Study. Giorgio Agamben and Educational Potentiality. New York: Routledge.

OZZIP (2014). Sprzątnąć wyzysk - sprzątaczki w sądzie. Pobrane z: http://www.ozzip.pl/teksty/informacje/wielkopolskie/item/1774-sprzatnac-wyzysk-sprzataczki-w-sadzie (15.05.2018).

Pelias, R.J. (2017). Still Here, Writing, Trying to Be a Part of the Conversation. Cultural Studies $\leftrightarrow$ Critical Methodologies, 17 (4), 364-365. DOI: https://doi.org/10.1177/1532708617706130.

Rorty, R. (2009). Przygodność, ironia i solidarność. Warszawa: Wydawnictwo W.A.B.

Rorty, R. (2010). Spetnienie obietnicy naszego kraju. Toruń: Wydawnictwo Naukowe Uniwersytetu Mikołaja Kopernika.

Ruitenberg, C.W. (2017). Reconceptualizing Study in Educational Discourse and Practice. New York: Routledge.

Rutkowiak, J. (2009). O oporze i odporze edukacyjnym: kreatywność oporu realizuje się w odporze. W: E. Bilińska-Suchanek (red.), Kreatywność oporu w edukacji (s. 14-38). Toruń: Adam Marszałek.

Shore, C., Taitz, M. (2012). Who 'owns' the university? Institutional autonomy and academic freedom in an age of knowledge capitalism. Globalisation, Societies and Education, 10 (2), 201-219. DOI: 10.1080/14767724.2012.677707.

Sitri, M. (2006). Horizontalism. Voices of Popular Power in Argentina. Edinburgh-Oakland: AK Press.

Stańczyk, P. (2013). Człowiek, wychowanie i praca w kapitalizmie. W stronę krytycznej pedagogiki pracy. Gdańsk: Wydawnictwo Uniwersytetu Gdańskiego.

Sztompka, P. (2017). Autonomia: fundament kultury akademickiej. W: Autonomia uczelni i środowiska akademickiego - odpowiedzialność i etos akademicki (s. 29-34). Warszawa: Instytut Problemów Współczesnej Cywilizacji im. Marka Dietricha.

Szwabowski, O. (2015a). Agambenowska szczelina edukacyjna. Recenzja Tyson E. Lewis, On Study: Giorgio Agamben and Educational Potentiality, Routledge 2013. Pedagogika Szkoły Wyższej, 1, 121-134. DOI: 10.18276/psw.2015.1-08.

Szwabowski, O. (2015b). Ruch Occupy: inna demokracja, inna pedagogika. W: A. Olczak, P. Prüfer, D. Skrocka (red.), Edukacyjne i spoteczne konteksty demokracji (s. 75-89). Gorzów Wielkopolski: Państwowa Wyższa Szkoła Zawodowa.

Szwabowski, O. (2016). The grey faces of academic workers: On the non-emancipatory resistance of Polish humanists to the edu-factory reform of academia. Journal for Critical Education Policy Studies, 14 (1), 44-56.

Szwabowski, O. (2017). Polityczność pedagogiki. Hybris, 36 (1), 60-72.

Szymaniak, M. (2018). Urobieni. Reportaże o pracy. Wołowiec: Czarne.

Wallerstein, I. (2008). Utopistyka. Poznań: Bractwo Trojka.

Winn, J. (2015). Pisanie o pracy akademickiej. Praktyka Teoretyczna, 4 (18), 20-43. DOI: 10.14746/ prt.2015.4.1. 


\section{Streszczenie}

W artykule autor wskazuje, że koncepcja autonomii może być niebezpiecznym konceptem. Opowiada się za kategorią zaangażowania i uniwersytetu złożonego.

Słowa kluczowe: edukacja wyższa, autonomia, zaangażowanie, pedagogika krytyczna

\section{AUTONOMY, EXODUS, COMMITMENT}

Summary

In the article author shows that concept of autonomy is a dangerous concept. Instead, he advocates a category of commitment and a complex university.

Keywords: higher education, autonomy, commitment, critical pedagogy 